\title{
Rural landscape and cultural routes: a multicriteria spatial classification method tested on an Italian case study
}

\author{
Irene Diti, Daniele Torreggiani, Patrizia Tassinari \\ Department of Agricultural Sciences, University of Bologna, Italy
}

\begin{abstract}
Europe is characterised by a rich net of itineraries that during the Middle Ages were taken by pilgrims head toward the holy places of Christianity. In Italy the main pilgrimage route is the Via Francigena (the road that comes from France), which starts from Canterbury and arrives in Rome, running through Europe for about $1800 \mathrm{~km}$. Municipalities and local associations are focused on purposes and actions aimed at the promotion of those routes, rich in history and spirituality. Also for the European Union the enhancement of those itineraries, nowadays used both by pilgrims and tourists, is crucial, as shown by the various projects aimed at the identification of tools for the development of sustainable cultural tourism. It is important to understand how landscape, that according to the European Landscape Convention reflects the sense of places and represents the image of their history, has evolved along those roads, and to analyse the relationships between the built and natural environments, since they maintain a remarkable symbolic connection between places and peoples over time and history. This study focuses on the Italian section of the Via Francigena that crosses the Emilia-Romagna region, in the province of Piacenza. A land classification method is proposed, with the aim to take into account different indicators: land zoning provided by regional laws, elements of relevant historical and natural value, urban elements, type of agriculture. The analyses are carried out on suitable buffers around the path, thus allowing to create landscape profiles.

As nature is a key element for the spirituality character of these pilgrimage routes, the classification process takes into account both protected and other valuable natural elements, besides agricultural activities. The outcomes can be useful to define tools aimed to help pil-
\end{abstract}

Correspondence: Daniele Torreggiani, Department of Agricultural Sciences, University of Bologna, viale G. Fanin 48, 40127 Bologna, Italy.

E-mail: daniele.torreggiani@unibo.it

Key words: Clustering, environmental and cultural heritage, global information system, landscape classification, Via Francigena.

Received for publication: 23 January 2015.

Accepted for publication: 19 March 2015.

(C) Copyright I. Diti et al., 2015

Licensee PAGEPress, Italy

Journal of Agricultural Engineering 2015; XLVI:451

doi:10.4081/jae.2015.451

This article is distributed under the terms of the Creative Commons Attribution Noncommercial License (by-nc 3.0) which permits any noncommercial use, distribution, and reproduction in any medium, provided the original author(s) and source are credited. grims and tourists to understand the surrounding places along their walk, as well as to lend support to rural and urban planning and integrated local development and landscape enhancement projects.

\section{Introduction}

In recent years many people have re-discovered the cultural routes, as opportunities for slow tourism and recreation activities, based on a balanced mix of culture and nature, and more intense relationships with the visited places and local communities. Pilgrimage routes, among cultural routes, have significantly contributed to the creation of the European identity. Between the $1^{\text {st }}$ and the $2^{\text {nd }}$ millennium B.C., Europe was a junction of streets used, besides merchants, soldiers, and travellers, by pilgrims head toward the holy places of Christianity. In Europe some signs of those itineraries can still be recognised clearly. Some of those roads are still used both by tourists and people who want to experience a spiritual research through pilgrimage. The most known paths in Europe are the Camino de Santiago (Route of Santiago de Compostela), from France to Spain, the Via Francigena (the road that comes from France) in Italy, the St. Olav's Way (Pilegrimsleden or Pilgrim's Route) in Scandinavia and the St. Michael's Way (route du Mont Saint-Michel) in France. There are many other itineraries, some of which officially acknowledged, some others used spontaneously from pilgrims and tourists.

This study is focused on the Via Francigena, in particular on its Italian part located in the Emilia-Romagna region (Italy), and is aimed to identify the different typologies of its surrounding landscapes, which represent crucial material and intangible aspects for tourists and pilgrims. The proposed methodology consists in a global information system (GIS) multi-criteria analysis. The strategic goals of this study is to define tools useful both to allow visitors to better understand the surrounding places and capture the meaning of their journey, as well as to lend support to rural and urban planning and integrated local development and landscape enhancement projects.

\section{The Via Francigena}

Italy has always been crossed by pilgrims, being Rome one of the main spiritual final destinations. Therefore, we can find many spiritual itineraries touching places, which are usually related to the Saints or Marian devotion. The main pilgrimage route that crosses Italy is the Via Francigena, which runs for about $1800 \mathrm{~km}$ across Europe. It is accessible by foot from the Canterbury Cathedral, it crosses France and the Italian-Swiss border and arrives in the Eternal City, Rome (North Francigena path), and also goes on along the Via Appia (Appian Way) up to Brindisi, in the Puglia region, ancient place were pilgrims used to board to Jerusalem (South Francigena path). Such path travelled through the eighty footsteps of the itinerary walked by Sigeric, the Archbishop of Canterbury, in 990 A.D., after Pope John XV asked him to note in a diary each stage of 
the way across Europe to return in England (Figure 1).

Over time the Via Francigena assumed more than only a spiritual function: it gained economical and commercial importance, especially from the Tuscany path, which became an important way for goods trade (Morelli, 2007). Therefore, the Via Francigena is more than a spiritual way: it can be described as a territorial system of relationships, trades, transformations, which over time has contributed, more than any other pilgrimage itinerary, to the creation of a urban net and European identity (Berti, 2012). Also for that reason in 1994 the Via Francigena was declared Cultural Route of the Council of Europe (Council of Europe, 2000, 2013). In order to enhance the Via Francigena along its whole itinerary, in 2001 the European Association of Vie Francigene (AEVF) was founded, with the aim to collaborate with the different institutions involved. The Via Francigena was visited by about 25,000 pilgrims and tourists in 2012, not many compared to those who use to walk each year through other paths, such as the Camino de Santiago (about 200,000 pilgrims in the same year) (Raju, 2014).

\section{Pilgrimage and cultural routes-based tourism}

We can consider pilgrimage as a common element in the main religions and faiths (Christianity, Islamism, Judaism and Oriental Philosophy). It represents the journey, made usually by foot, towards a holy or sacred place. Jerusalem, Santiago de Compostela or Rome (peregrination majores) for Christians, Mecca for Muslims, the Jerusalem Temple for Jews, or some famous temples in India for Hindus (Josan, 2009), are only a few examples of holy places visited each year by thousands of people. From a Christian point of view, pilgrimage has assumed, over the centuries, different meanings: the devotional pilgrimage (devotionis causa), the penitential pilgrimage (used to obtain indulgence of personal sins), and the judicial pilgrimage (used during the Inquisition). The devotional pilgrim is someone who reaches a shrine or a holy place, as Santiago de Compostela or Rome, in which each pilgrim has a document with the stamps of each step reached along the path. The devotional pilgrimage is usually experienced with a particular lifestyle, characterised by essentiality, pray, poverty, and attention to Providence.

The pilgrimage is a multidimensional experience that involves not only the spirit and the body, but also the perception of the values of the landscapes that are crossed, and the meaning that those landscapes have in the experience of each pilgrim (Maddrell and Della Dora, 2013). It is also an opportunity for research and contemplation of the Creation. Also in Christianity, the theological meaning of pilgrimage is a key point for the pilgrim who can participate in the Resurrection of Christ, in a way that starts his conversion path. Even when pilgrimage reaches places where no miracle happened, the way itself, rich in spirituality, implements changes (Slavin, 2003), as pilgrims are walking in search of something intangible (Solnit, 2000).

According to Lois-Gonzàlez and Santos (2014), there are three common elements in each pilgrimage: the way, the motivation, and the final destination. It is well known that not all the people who walk on pilgrimage routes are driven by the same motivations. Some visitors experience pilgrimage routes only as tourists. The word pilgrim actually comes from the Latin word tornus, referring to a journey that starts and finishes in the same place. During medieval times the word pilgrimage was used to underline spiritual journeys, and the word tourism was used for pleasure travel. So pilgrimage does not only represent an opportunity for humans to encounter the Divine, but also a way to overcome geographical boundaries and distances, and a chance to meet new people and admire new places (Cerrutti and Dioli, 2013). Depending on the typologies of users' attitudes and interests, cultural heritage and natural landscape components have different important meanings. Landscape, as an aspect directly perceivable in the territori- al system, is a key element in the evaluation of tourists' experience (Croce and Perri, 2009). Over the last decades many studies have focused on the motivations of pilgrimage and the impact of tourists on pilgrimage routes (Cerrutti and Dioli, 2013; Collins-Kneiner, 2010; Murray and Graham, 1997).

\section{The landscape along the path}

Pilgrimage is strongly joined to landscape, because it can be considered a journey to a place with a peculiar metaphysical meaning, and at the same time a journey through and in the landscape (Scriven, 2014). Paths and roads are key elements that condition landscape evolution. Pilgrims experience the landscape from the streets, thus landscape becomes a dynamic element, changing at every step and telling the history of the surroundings. Nowadays people have partially lost the ability of interacting with their places and nature through culture and spirituality, due to many artificial cognitive filters. However, during their journey, the distance between pilgrims and the environment is shortened (Caliandro et al,. 2014). Walking changes time dimension and allows to perceive differently the meaning of landscape (Falqui and Serenelli, 2009). No doubt the Via Francigena has lost some of its original characteristics, crossing and mingling in some points with more modern roads (for example the Via Emilia, in the case study), but the word journey helps us to better understand the relationships between landscape and the way in the context of the soul way, a sort of personal journey. Landscape becomes the point of tension, the line of contact between the visible and the invisible, the material and the intangible (Maddrel and Della Dora, 2013). The landscape is told by the way, which is a type of reading reality that helps to understand the meaning of its signs, combining together the time and spatial dimensions, giving rise to a form of tale (Turri, 1998). The use of walking into landscape as an art is interesting: one only needs to think to the famous operas by Richard Long and Hamish Fulton, land artists who have made of the relationships between route, landscape and nature their form of art.

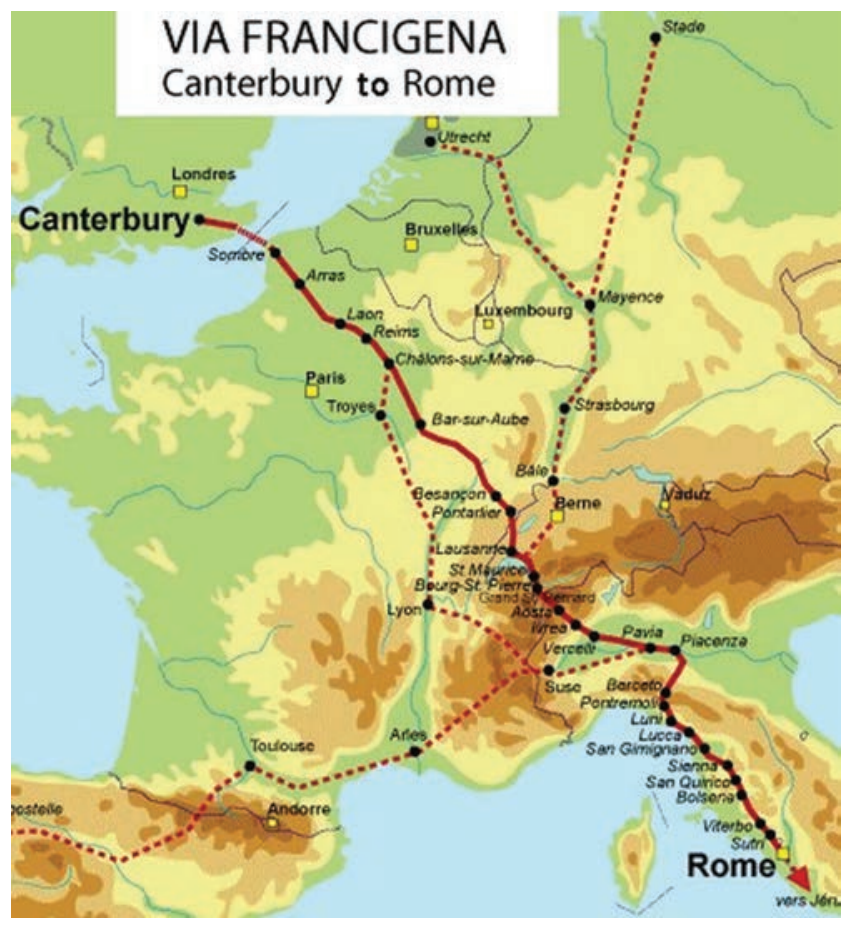

Figure 1. The Via Francigena according to Sigeric's itinerary (Council of Europe). 


\section{Via Francigena and territorial planning}

The Via Francigena is a land element that should be a crucial element of spatial planning, as it may represent a driving force for the development of a sustainable and conscious tourism, aimed to experience the territory, especially the countryside, walking and admiring the surrounding landscape resources. According to the European Landscape Convention, policies aimed at landscape protection and management should be consistent with local cultural identity. Pilgrimage ways represent marked and characterised historical land elements. Those cultural itineraries can become places based on which it is possible to drive a territorial development consistent with the identity of places (Cerruti and Dioli, 2013). Along Pilgrimage Routes, nowadays pilgrims and tourists can find signs of ancient pilgrimage such as churches, fountains, bridges or sculptures that should be enhanced in the pilgrim and tourist guides and in rural planning. Along the Via Francigena, old paths have been repaired and enhanced, but a comprehensive analysis of the natural, historical and cultural resources along the paths is necessary. Some Italian regions are strongly active on a coordinated and shared management of the Via Francigena through a strategic planning tool, a Route Master Plan which is connected with other sectorial plans. Moreover, municipalities should implement and increase policies and actions, in collaboration with national and international pilgrimage and cultural route associations and local institutions, to provide users with a pleasant walk, also allowing broader positive consequences on the local economy.

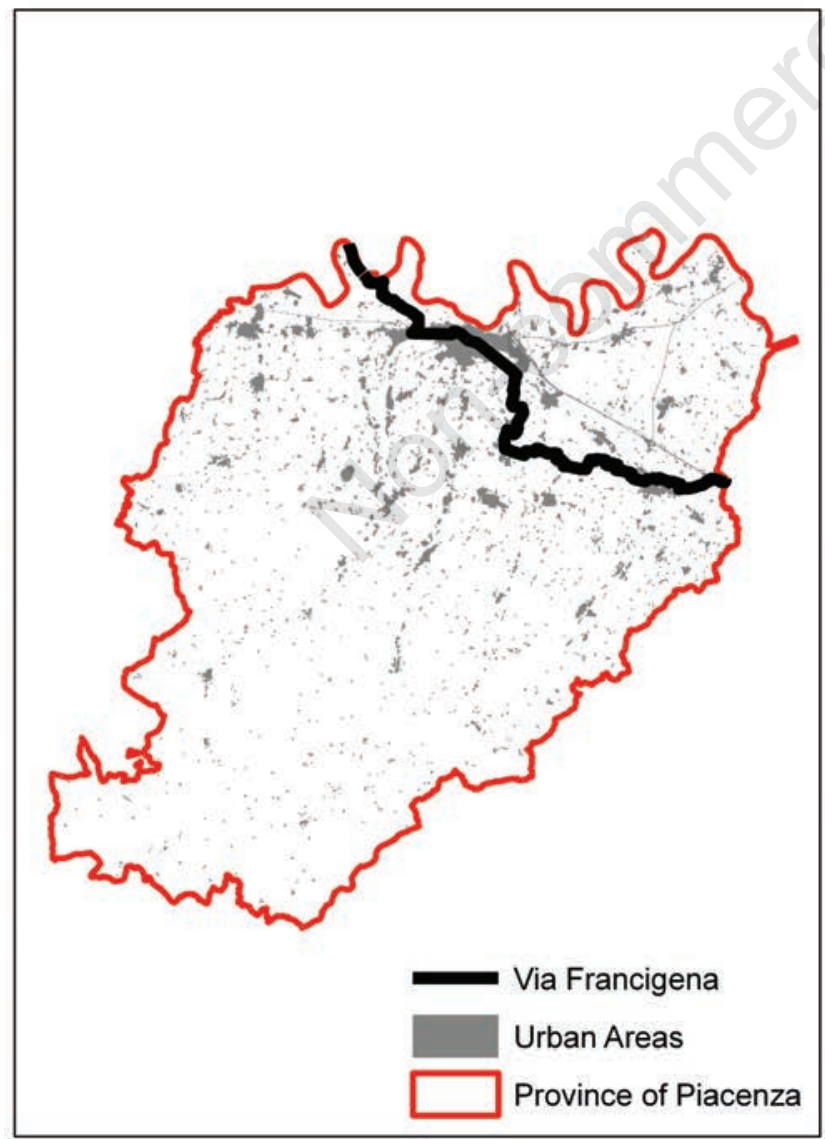

\section{Materials and methods}

\section{Study area and tools}

The research is based on the assumption that landscape has a fundamental role in pilgrims' and tourists' journeys along the pilgrimage routes, and its understanding calls for a thorough analysis of the different landscape components. Furthermore landscape is not only a scene, but also a place to be experienced.

The study has been implemented on a portion of the Via Francigena crossing the Emilia-Romagna region, between Orio Litta and Fiorenzuola, in the Piacenza province. The path is $60.9 \mathrm{~km}$ long, along three route steps, and crosses the Po valley (Figure 2). The Piacenza province has a territorial extent of $2.59 \mathrm{~km}^{2}$ and is the most western part of the region. In order to describe the landscapes crossed by the walkers during their journey on the Via Francigena, the analysis is focused on a $4 \mathrm{~km}$ wide buffer around the path, $2 \mathrm{~km}$ on each side, which corresponds to a one-hour walking distance, considered an acceptable detour from the main path (Wolf and Meyer, 2010; Fumagalli et al., 2013).

The methodology has been developed in a GIS, with reference to basic information derived from maps, statistical and administrative data that can be easily find in public databases. This allows an easy database population and thus increases the methodology reproducibility and extendibility. GIS calculations have been developed by means of ArcMap 9.2 by ESRI (2009), its spatial analyst extension, and V.LATE 1.1

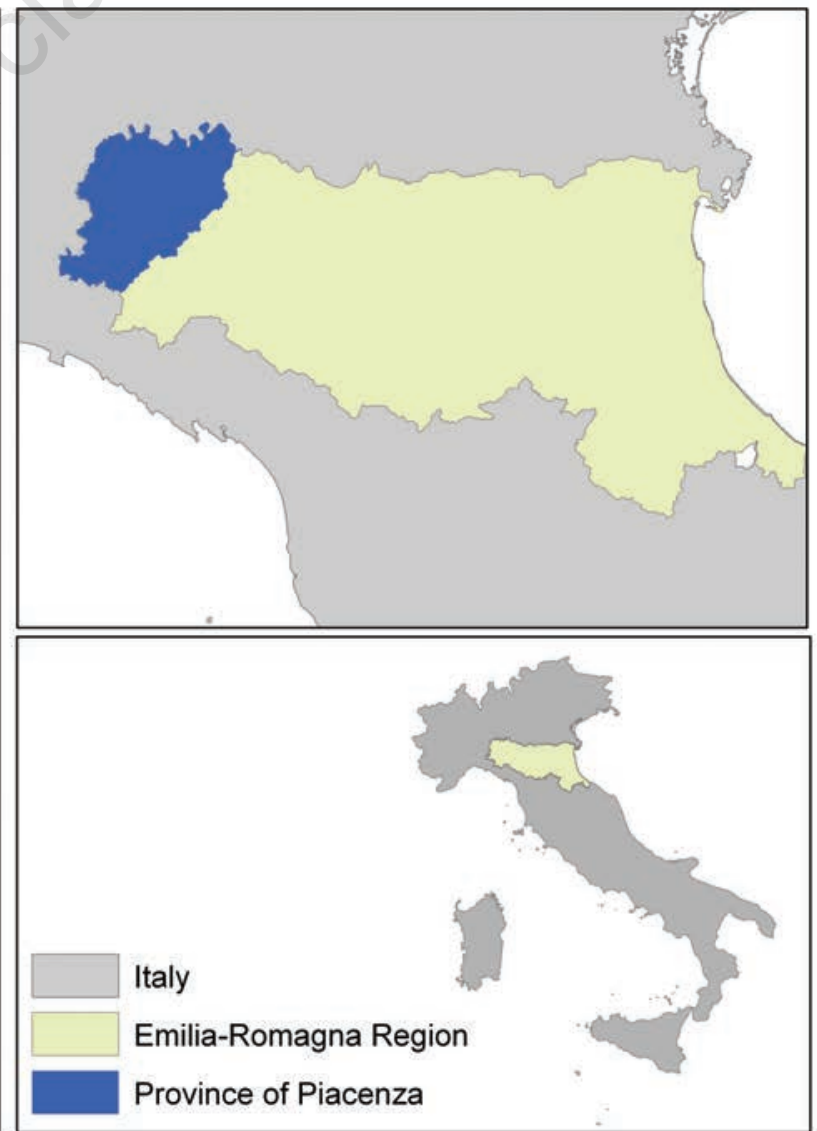

Figure 2. Study area. 
(Vector-Based Landscape Analysis Tool developed within the European project SPIN) (University of Salzburg, 2004). In particular, for the clustering and classification phases the IsoCluster algorithm and an unsupervised classification procedure (maximum likelihood classification) have been used.

\section{Criteria elaboration}

The description of landscapes crossed by the Via Francigena is performed through the combined analysis of variables referred to different elements that characterise the landscape from the user's point of view. The diagram of Figure 3 shows the methodological process, developed for the classification of the different landscape typologies. A multidisciplinary approach has been used to select the variables, based both on an in-depth analysis of the scientific literature (in the geography, agronomy, and socioeconomic fields) and a discussion with a panel of experts. This has allowed to point out the main features characterising the walkers' experience (Table 1), focusing in particular on natural and ecological values of landscape elements, accessibility of paths, urban influence, and landscape change.

The natural and ecological landscape feature are described through the evaluation of density of ecological elements, derived from the analysis of natural and protected areas (PROT_AREAS and NATU_AREAS). The Natura 2000 network database, the Provincial Territorial Land Plan and land-use maps have been analysed. Land-use maps were produced by the Emilia-Romagna region according to the CORINE land cover (CLC) methodology. Minimum map unit is 0.375 ha for 1976, and 1.56 ha for 2008 . We have considered the third level of the CLC legend, for a total of 44 categories, in order to focus the calculation of metrics and clustering and classification phases on non-urban areas.

Rural landscape is a crucial element in regional planning. It is deeply characterised by agricultural activities, which create different scenes depending on the various agriculture typologies (AGRI_TYPO). Those land types have been derived from land-use map, focusing on CLC second-level legend items, within the first level Agricultural areas class. We have assigned them values ranging from 100 to 0 (arable land, grasslands, vineyards, poplars, other cultivations, vegetables, complex agricultural systems and plant nursery), in order to assess their potential impact on the natural character of the surrounding environment, based on the incidence of anthropic processes in the management of the area. Another key element considered in the analysis of landscape typologies is the history of the crossed territories. Therefore we have considered the density of historical elements (such as churches, monuments, urban centres), derived from provincial plans. Routes usability also depends on the availability of accommodation structures. We have focused on agri-tourism farms (HOSPI), given their strong relationships with the surrounding landscapes and multifunctional attitude. Such data have been provided by Regional Tourism Office. Availability of further services has been evaluated, by calculating the density of specific elements, such as water springs and fountains (WATER). Those data were acquired by the Emilia-Romagna database and integrated in the GIS by means of digitalisation based on the official Pilgrims' Guide. Incidence of infrastructures on landscape, especially roads and railways, has been evaluated by computing their linear density (ROAD_RAIL). Since pilgrims do not usually use their own cars to reach the first step of the Way, we have also considered the density of railway stations along the path (STATION).

The evolution of the landscape mosaic (LAND_DYNA) has been analysed by comparing land use in 1976 and 2008, assigning to each land-use trend different values based on the level of conservation of historical and natural landscape elements. Those analyses have been based on the evaluations performed by a panel of experts. Land use categories have been analysed focusing on CLC third-level legend items (740 possi- ble combinations). The following landscape changes have been considered, listed with decreasing landscape impact and increasing landscape value: urbanisation, deforestation, intensification, extensification, forestation, no change, ruralisation and naturalisation.

In order to analyse landscape fragmentation, we have computed the corrected perimeter-area index (CPA) (Farina, 1998). Values near to one indicate regular forms, while values higher than one are typical of fragmented landscape mosaics, which have been evaluated as negative features in walkers' experience.

Clustering and GIS classification procedures require comparable values of all variables. Therefore input data have first been analysed in vector format using the GIS. Some non-continue variables have been calculated as a density surface, with a $2 \mathrm{~km}$ search radius (as for buffer analysis, distance has been chosen based on its conversion in 0.5 walking hours). Maps have then been converted into raster maps, whose $100 \mathrm{~m}$ pixel size has been determined as a function of the minimum map unit of input data (Hengl, 2006). Since the chosen clustering algorithm calls for a preliminary data homogenisation, input values have been normalised according to a minimum-maximum approach, based on the distance from the best and worst performers, and reclassified on a scale from 0 to 100 in order to quantify the potential agri-environmental impact on the urban system. This method has been defined

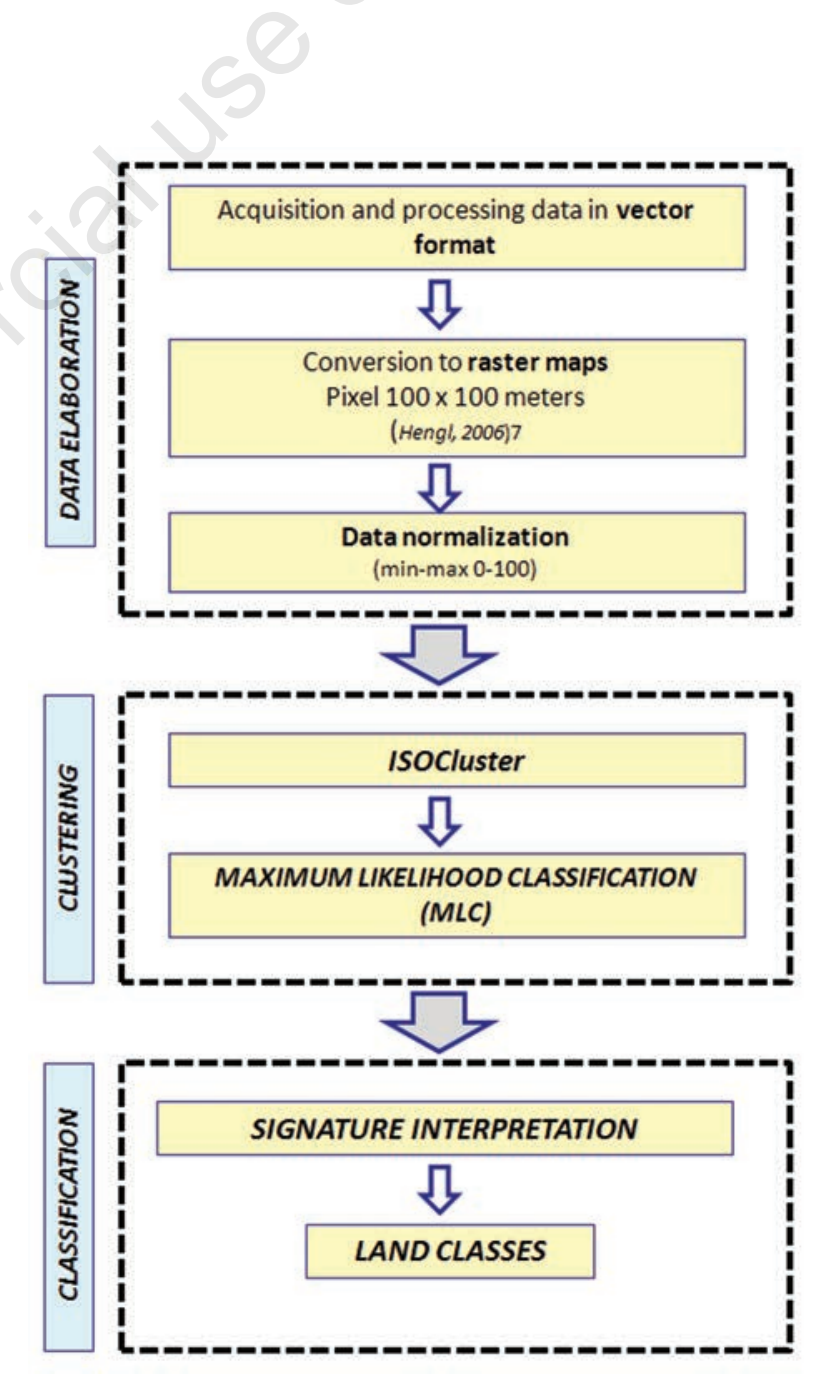

Figure 3. Methodological framework for the identification of landscape classes. 
based on criteria defined by a panel of experts, to allow comparable value ranges for all indicators. It is important to highlight that the direction of the function depends on the meaning of the indicator in respect of landscape environmental quality. Therefore, in cases when high variable values corresponded to negative impacts on landscape quality, normalised values were further reclassified by inverting the function direction.

In order to understand the statistical significance of the chosen variables, a correlation analysis has been performed using the GIS software, by calculating the Pearson's correlation index, in order to assess any significant relationships among the indicators and, if needed, to exclude redundant variables. The results have shown a high correlation between $R O A D \_R A I L$ and $U R B \_D E N(\mathrm{r}=0.81)$. Therefore, $R O A D \_R A I L$ has been excluded from the following analyses.

We have combined the data in a multidimensional environment, by means of the IsoCluster algorithm, an automatic iterative clustering method where each element (pixel) is assigned to a given cluster based on the minimum Euclidean distance. The following classification procedure has been performed by means of a maximum likelihood classification method that, starting from a set of raster datasets and a signature which is the output of the clustering procedure, allows to assign each pixel to a cluster, thus leading to the land classes map.

\section{Results and discussion}

We present and discuss here the first results of the implementation of the method on the above-described study area. Reclassified raster maps of each indicator have been used as input for the IsoCluster procedure, with the aim to define the cluster/spatial units with the highest interior similarity, and the highest diversity among clusters. Each cluster can be described through a signature, consisting in a vector whose vertexes are the average values of the indicators of a given cluster (Figure 4). Such outcomes have been used as input for the maximum likelihood classification. The results of the clustering process show that the maximum number of separable classes for that case study is equal to four, named from LAND_A to LAND_D (Figure 5). Each class has been analysed based on a compared analysis of the signatures, thus, allowing to describe each landscape typology, as follows:

- LAND_A. This class includes small areas close to urban centres along the path. It is characterised by low values of all indicators, except for $U R B \_D E N$. The impact of urban areas is confirmed from low values of $L A N D \_D Y N A$ and $C P A$, which indicate urbanisation and deforestation phenomena and low fragmentation in the landscape mosaic.

- LAND_B. This class is located far from the main urban centres. High values of $L A N D \_D Y N A$ indicate ruralisation phenomena or no landscape changes. This is confirmed by $C P A$ values. Values near to zero of WATER, STATION and HOSPI are related to poor services for pilgrims. URB_DEN, NATU_AREA, and PROT_AREAS low values indicate both a limited impact of urban areas and a small amount of natural and protected areas.

- LAND_C. This class is located mainly close to the urban centre of Piacenza, on the sides of the Trebbia river in the western part of the city and between Piacenza and Carpaneto Piacentino. High density of historical elements and fountains or springs have been found, while there is no presence of railway stations. This class presents the highest values for PROT_AREA, but land use patterns present higher fragmentation, and land-use change analysis show no change or forestation/ruralisation phenomena.

- LAND_D. This class is located in the eastern part of the route, between the Trebbia river and Piacenza, close to small urban centres. The high values of density of natural areas, accommodation farms, and stations show high service levels for pilgrims; at the same time, $U R B \_D E N$ and $C P A$ values show a significant urban influence and a fragmented rural landscape, respectively.

Table 1. Description of selected variables and typologies of data used.

\begin{tabular}{llll} 
Index & Name & Description & Data used \\
PROT_AREAS & Natural protected areas & $\begin{array}{l}\text { Density of protected areas } \\
\text { (SCI-SPA and regional and national parks) }\end{array}$ & $\begin{array}{l}\text { Natura 2000 Maps } \\
\text { Provincial Territorial Plan }\end{array}$ \\
NATU_AREAS & Areas with high natural and ecological value & Density of natural areas such as forests, waterlands & $\begin{array}{l}\text { Provincial Territorial Plan } \\
\text { Land Use Map (2008) }\end{array}$ \\
\hline AGRI_TYPO & Agricultural land use typologies & $\begin{array}{l}\text { Agricultural typologies classified in order to assess } \\
\text { their potential impact on natural environments }\end{array}$ & Land Use Map (2008) \\
HISTO & Historical elements & Density of historical elements & Provincial Territorial Plan \\
\hline WATER & Springs and fountains & Density of water springs and fountains & Pilgrims' Guide \\
EOSPI & Hospitality & Density of agro-tourism farms & Emilia-Romagna region database \\
\hline URB_DEN & Urban density & Density of urban areas & Land Use Map (2008) \\
ROAD_RAIL & Infrastructure density & Density of road and rail infrastructure & Provincial Territorial Plan \\
\hline STATION & Railway station density & Density of railway station & Emilia-Romagna region database \\
CPA & Landscape fragmentation & $\begin{array}{l}\text { Landscape fragmentation analysis } \\
\text { through the corrected perimeter-area index }\end{array}$ & Land Use Map (2008) \\
\hline LAND_DYNA & Landscape evolution & Quantification of changes in the landscape & Land Use Map (1976-2008) \\
\end{tabular}

SCI, site of Community importance; SPA, special protection area. 


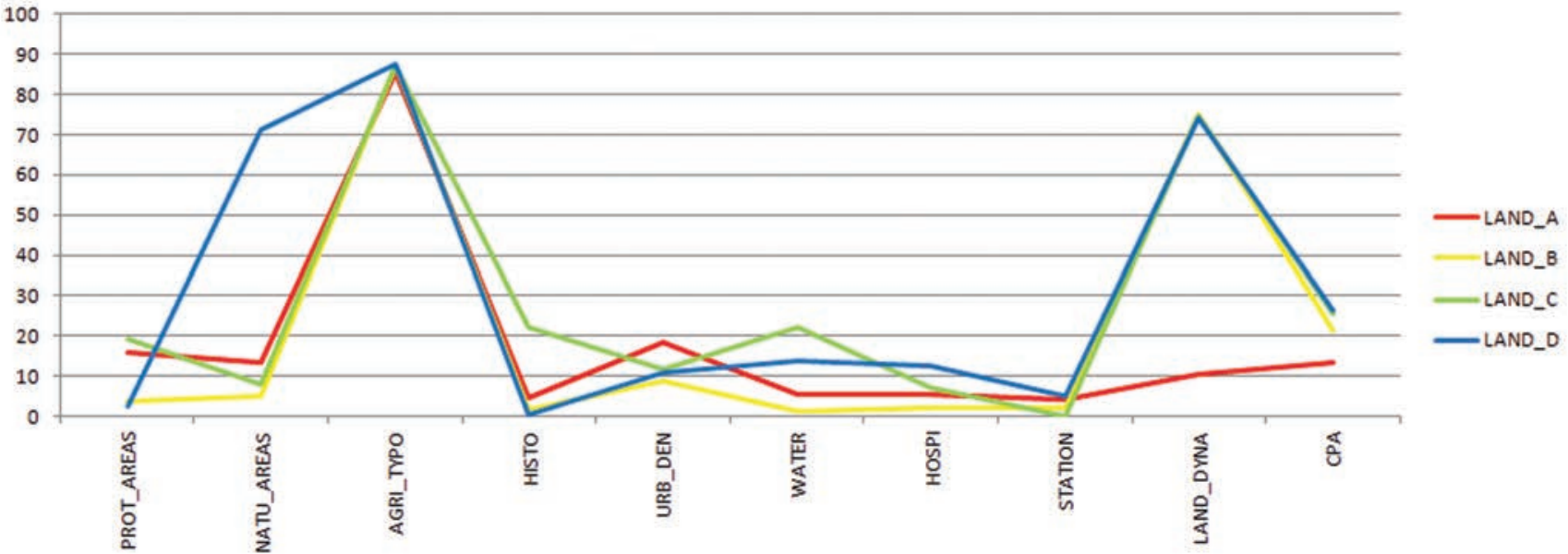

Figure 4. Landscape classes signatures. PROT_AREAS, natural protected areas; NATU_AREAS, areas with high natural and ecological value; AGRI_TYPO, agricultural land use typologies; HYSTO, historical elements; URB_DEN, urban density; WATER, springs and fountains; HOSPI, hospitality; STATION, railway station density; LAND_DYNA, landscape evolution; CPA, corrected perimeter-area index for landscape fragmentation.

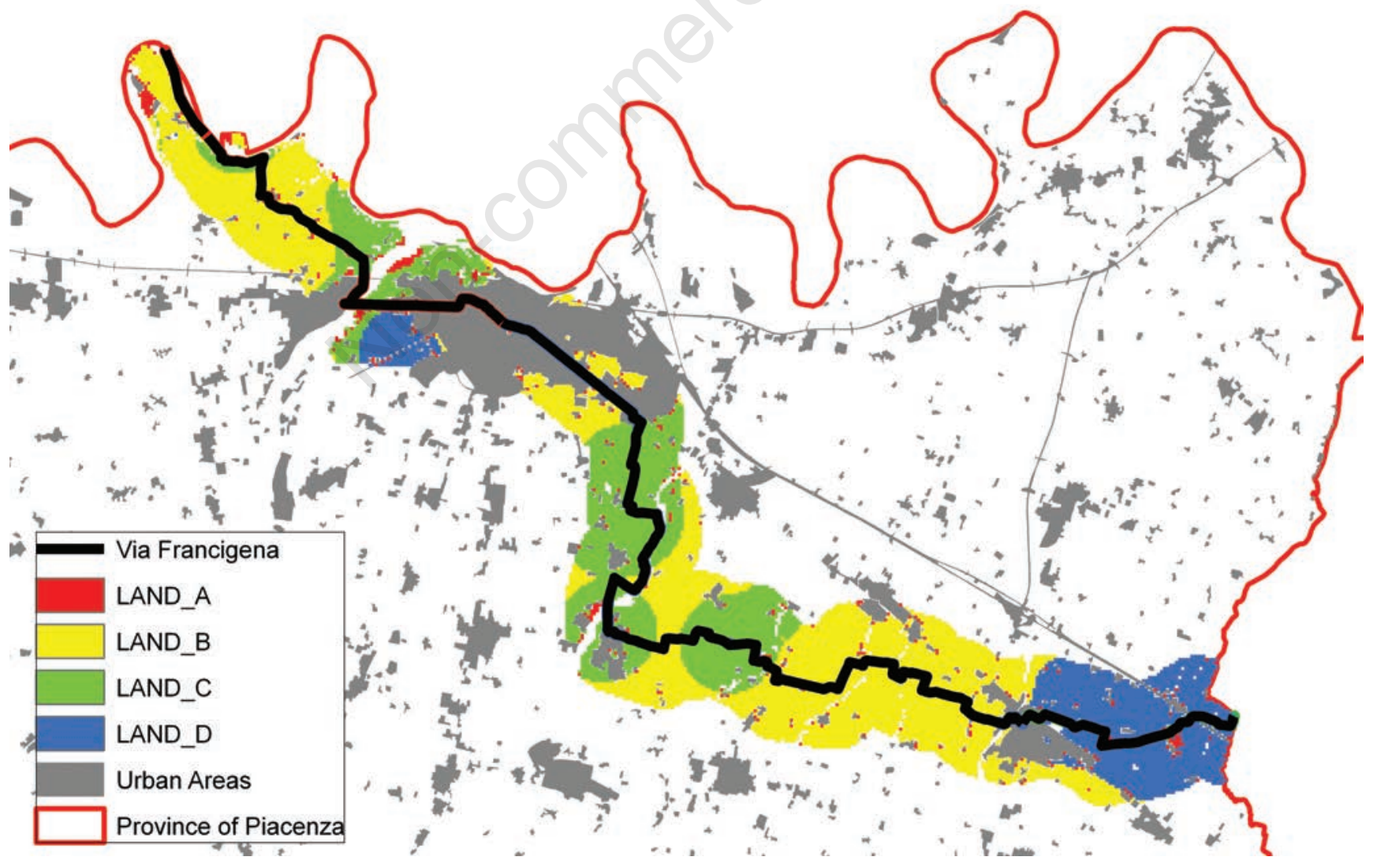

Figure 5. Landscape classification of the Via Francigena landscape after clustering and maximum likelihood classification. 


\section{Conclusions and further developments}

The goal of this research was the identification of landscape classes along the pilgrimage route, on the Via Francigena case study, to lend support to both tourism and pilgrimage organisation, and rural planning processes.

First of all, the findings can be useful to pilgrims and tourists, since the information provided with reference to the interpretation of landscape classes' features can be used in order to develop site signage along the paths, to provide tourists with useful information about the landscape status, changes and functions. Moreover, those information can be uploaded on specific websites or mobile mapping applications used to interactively provide pilgrims and tourists with useful geolocalised information (such as photographs and descriptions of the most relevant surrounding landscape elements, information about accommodation and other services, etc.).

In the spatial planning context, the proposed methodology can help planners to read landscape from a new perspective, allowing better policies for the enhancement of cultural, natural and economical resources to be defined. The use of databases frequently used by local administrations allows a wide applicability of the proposed model within the planning processes.

Moreover, the method is based on an objective and multicriteria approach, which goes beyond the overlay of different layers, being based on a sound statistical approach. The set of indicators can be adapted in order to highlight the characteristic of different areas crossed by the Via Francigena or other pilgrimage and cultural routes. The implementation of the proposed multicriteria methodology on the study area has allowed identifying different landscape classes, which would have hardly been recognisable through classic sectorial analyses, thanks to the ability of considering the relationships among the various variables of the proposed cluster analysis approach. As a result, spatially distant areas can show similar agro-environmental profiles and functions and thus be classified in the same landscape class. Each landscape class has been described by a joint reading of the variables that characterise their natural, ecological, cultural, and social elements. Further developments should be aimed to test the method on a wider buffer area, or on different case studies, and to integrate and calibrate new criteria in order to better describe the walkers' experience, also using direct on-site interview. Moreover, further developments could be aimed to experiment additional statistical elaborations.

\section{References}

Berti E. 2012. Itinerari culturali del consiglio d'Europa tra ricerca di identità e progetto di paesaggio. Firenze University Press, Firenze, Italy.
Caliandro L.P., Loisi R.V., Dal Sasso P. 2014. Connections between masserie and historical roads system in Apulia. J. Agricult. Engine. 45:15-23.

Cerruti S., Dioli I. 2013. Via Francigena mountain itineraries: the case of Piacenza valley. Int. J. Religious Tourism Pilgrimage. 1:83-92.

Collins-Kreiner N. 2010. Researching pilgrimage. Continuity and transformations. Ann. Tourism Res. 37:440-56.

Council of Europe, 2000. European Landscape Convention; 20 October, Florence, Italy. Available from: http://www.coe.int/t/dg4/cultureheritage/heritage/Landscape/default_en.asp

Council of Europe, 2013. Resolution CM/Res(2013)67 revising the rules for the award of the "Cultural Route of the Council of Europe" certification. Available from: https://wcd.coe.int/ViewDoc.jsp?id $=2143643 \&$ Site $=$ CM

Croce E., Perri G. 2009. Il paesaggio, sfondo scenografico 0 realtà geografica da gustare nel turismo eno-gastronomico. Ri-Vista 11:59-64.

Falqui E., Serenelli C. 2009. Viaggi spirituali, itinerari culturali e cammini per lo sviluppo. Ri-Vista 11:27-33.

Farina A. 1998. Principles and methods in landscape ecology. Champan and Hall, London, UK.

Fumagalli N., Colombo C., Ferrario P.S., Senes G., Toccolini A. 2013. Suburban waterfront with ecological and recreational function: planning based on network analysis. J. Agricult. Engine. 44:141-52.

Hengl T. 2006. Finding the right pixel size. Comput. Geosci. 32:1283-98.

Josan I. 2009. Pilgrimage - A rudimentary form of modern tourism. GeoJ. Tourism Geosites. 4:160-8.

Lois-Gonzàlez R.C., Santos X.M. 2014. Tourist and pilgrims on their way to Santiago. Motives, caminos and final destinations. J. Tourism Cult. Change 15:1-16.

Maddrell A., Della Dora V. 2013. Crossing surface in search of the Holy: landscape and liminarity in contemporary Christian pilgrimage. Environ. Plan. A. 45:1105-26.

Morelli E. 2007. Strade e Paesaggi della Toscana. Il paesaggio dalla strada, la strada come paesaggio. Alinea Editrice, Firenze, Italy.

Murray M., Graham B. 1997. Exploring the dialectics of route-based tourism: the Camino de Santiago. Tourism Manage. 18:513-24.

Raju A. 2014. The Via Francigena - Pilgrim trail Canterbury to Rome Part 2: The great St. Bernard pass to Rome. Cicerone Press, Milnthorpe, UK.

Scriven R. 2014. Reflecting on the pilgrim path: routes, landscapes and performing bodies. In Proc. CIG2014 46th Conf. Irish Geography, 6th-10th May 2014. UCD, Dublin, Ireland.

Slavin S. 2003. Walking as spiritual practice: the pilgrimage to Santiago de Compostela. Body Soc. 9:1-18.

Solnit R. 2000. Storia del camminare. Mondadori, Milano, Italy.

Turri E. 1998. Il paesaggio come teatro: dal territorio vissuto al territorio rappresentato. Marsilio, Padova, Italy.

Wolf T., Meyer B.C. 2010. Suburban scenario development based on multiple landscape assessment. Ecol. Indicat. 10:74-86. 